\title{
Tourism Preferences Towards Blendung Beach and Nyamplungsari Beach in Pemalang Regency
}

\author{
Sevilla Inta Cahayani ${ }^{\bowtie}$ \\ Jurusan Ekonomi Pembangunan, Fakultas Ekonomi, Universitas Negeri Semarang \\ Permalink/DOI: https://doi.org/10.15294/efficient.v2i2.30804 \\ Received: December 2018 ; Accepted: March 2019; Published: Juny 2019

\section{Abstract}

This study aims to determine and analyze how are tourists' preferences towards Blendung Beach and Nyamplungsari Beach attractions in Pemalang Regency by analyzing the characteristics of tourists and the factors that influence tourist interest in Blendung Beach tourism attractions and Nyamplungsari Beach so that the number of tourist visits can increase and be able to compete with other tourist objects. The research method used is quantitative research method with a sample of 100 respondents and using the preference values used are very good (4.6-5.0), good (3.6-4.5), good enough (2.6-3, 5), less good (1.6-2.5) and not good (1.0-1.5). The results showed that tourist preferences towards both tourism objects Blendung Beach and Nyamplungsari Beach were in accordance classified as good enough, but also there were still indicators in the unfavorable and bad categories. Therefore there is a need efforts to improve tourist ratings and preferences so that it is expected to be able to encourage the increase in the number of tourist visits.
\end{abstract}

\section{Keywords: Preferences, tourism, Blendung Beach, Nyamplungsari Beach}

\begin{abstract}
Abstrak
Penelitian ini bertujuan untuk mengetahui dan menganalisis bagaimana preferensi wisatawan terhadap objek wisata Pantai Blendung dan Pantai Nyamplungsari di Kabupaten Pemalang dengan menganalisis karakteristik wisatawan dan faktor-faktor yang mempengaruhi minat wisatawan di objek wisata Pantai Blendung dan Pantai Nyamplungsari sehingga jumlah kunjungan wisatawan dapat meningkat dan dapat bersaing dengan objek wisata lainnya. Metode penelitian yang digunakan adalah metode penelitian kuantitatif dengan sampel 100 responden dan menggunakan nilai preferensi yang digunakan sangat baik $(4,6-5,0)$, baik $(3,6-4,5)$, cukup baik $(2,6-3,5)$, kurang baik $(1,6-2.5)$ dan tidak bagus (1.o-1.5). Hasil penelitian menunjukkan bahwa preferensi wisatawan terhadap kedua obyek wisata Pantai Blendung dan Pantai Nyamplungsari itu sesuai diklasifikasikan cukup baik, tetapi juga masih ada indikator dalam kategori tidak menguntungkan dan buruk. Oleh karena itu diperlukan upaya untuk meningkatkan peringkat dan preferensi wisatawan sehingga diharapkan dapat mendorong peningkatan jumlah kunjungan wisatawan.
\end{abstract}

Kata Kunci: Preferensi, pariwisata, Pantai Blendung, Pantai Nyamplungsari

How to Cite: Cahayani, S. (2019). Tourism Preferences Towards Blendung Beach and Nyamplungsari Beach in Pemalang Regency. EFFICIENT Indonesian Journal of Development Economics, 2(2), 452-46o. https://doi.org/10.15294/efficient.v2i2.30804

(C) 2019 Semarang State University. All rights reserved

\footnotetext{
Alamat Korespondensi :

Alamat: Gedung L2 Lantai 2 FE Unnes

Kampus Sekaran, Gunungpati, Semarang, 50229

E-mail : sevillaintacahayani73@gmail.com
}

ISSN 2655-6197 


\section{INTRODUCTION}

The enactment of Law No. 10 of 2009, about tourism is expected to spur tourism development in the era of regional autonomy. Pemalang Regency is an area that has a potential to be developed, especially tourism object, in this case Blendung
Beach and Nyamplungsari Beach. This potential can be seen from its natural panorama that is still beautiful, and its strategic location that is located around Pantura streets which is a cross - city road.

Table 1. Data of Total Tourists to Tourism Objects per Month in Pemalang Regency 2012-2016

\begin{tabular}{lccccc}
\hline \multirow{2}{*}{ Month } & \multicolumn{5}{c}{ Number of Tourists (Person) } \\
\cline { 2 - 5 } & $\mathbf{2 0 1 2}$ & $\mathbf{2 0 1 3}$ & 2014 & 2015 & 2016 \\
\hline January & 67.212 & 85.304 & 61.127 & 93.356 & 100.750 \\
February & 42.638 & 39.820 & 30.417 & 44.585 & 57.621 \\
March & 58.105 & 60.717 & 44.562 & 53.160 & 71.558 \\
April & 56.350 & 48.131 & 40.204 & 51.259 & 61.644 \\
May & 74.112 & 66.260 & 56.392 & 71.097 & 84.684 \\
June & 93.289 & 87.982 & 65.846 & 46.875 & 41.607 \\
July & 59.927 & 41.923 & 103.098 & 175.444 & 189.854 \\
August & 216.231 & 202.393 & 130.549 & 60.594 & 60.021 \\
September & 51.372 & 40.334 & 39.026 & 58.335 & 71.340 \\
October & 54.854 & 51.966 & 59.566 & 154,365 & 69.508 \\
November & 53.833 & 41.798 & 39.026 & 58.335 & 71.340 \\
December & 64.649 & 69.648 & 70.568 & 95.821 & 128.020 \\
Total & 892.572 & 836.276 & 740.477 & 961.127 & 1.011 .319 \\
\hline
\end{tabular}

Source: Pemalang Regency Central Statistics Agency, 2017

Based on Table 1 tourists visiting Blendung Beach from 2012 were 58,601 people have increased in 2013, and from 2013 the number of tourist visits experienced a decline until 2016. While the number of tourists visiting Nyamplugsari Beach from 2012 to 2016 continued to decline . Compared to Blendung Beach and Nyamplungsari Beach, the number of Widuri Beach tourist visits is still more, although it tends to decrease but not so significantly. This indicates that tourists visiting Pemalang Regency still choose to visit Widuri Beach rather than visiting Blendung Beach and Nyamplungsari Beach.

The tendency of increasing the number of tourist visits in Pemalang Regency every year is not separated because the tourism objects in Pemalang Regency are in great demand by the community. This condition is not in line with data on the number of tourists visiting the Blendung Beach and Nyamplungsari Beach which tend to experience a decrease in the number of visitors from 2012 to 2016. With the potential that exists, it is unfortunate that some potentials 
have not been developed optimally so that these tourism objects are still not well known and in demand by the wider community. Tourist interest in a tourist attraction is influenced by several factors that can provide pleasure and convenience in making travel. One of the things that tourists consider in choosing a tourist object to visit is the preference of tourists. Tourist preference is an assessment or choice of likes / dislikes of tourists towards a tourism object that is assessed from several indicators such as tourist attraction, tourist accessibility, tourist facilities and tourist services. Thus, the tourism objects of Blendung Beach and Nyamplungsari Beach still do not play a role in supporting the number of tourists in Pemalang Regency, which each year experiences an increase with tourists visiting Pemalang Regency tend to travel by choosing tourist attractions.

Table 2. Data on the Total of Tourists of Widuri Beach Tourism Object, Blendung Beach and Nyamplungsari Beach Pemalang Regency in 2012-2016

\begin{tabular}{lccccc}
\hline \multirow{1}{*}{ Tourism Object } & \multicolumn{5}{c}{ Number of Tourists (Person) } \\
\cline { 2 - 6 } & 2012 & 2013 & 2014 & 2015 & 2016 \\
\hline Widuri Beach & 212.599 & 202.017 & 158.061 & 169.373 & 162.573 \\
Blendung Beach & 58.601 & 60.572 & 19.973 & 9.900 & 6.872 \\
Nyamplungsari Beach & 36.080 & 34.896 & 10.400 & 9.900 & 7.850 \\
\hline
\end{tabular}

Source: Pemalang Regency Central Statistics Agency, 2017

Based on table 3, the highest income were only in 2012. To find out how the from the three tourism objects is Widuri rating and preference of tourists towards Beach, while the income of Blendung the attractions of Blendung Beach and Beach tourism from 2012-2016 tends to Nyamplungsari Beach in more detail, decrease. At Nyamplungsari Beach tourism, the penlis are interested in conducting the data obtained by researchers this research.

Table 3. Total Revenues of Widuri Beach, Blendung Beach and Nyamplungsari Beach Revenues in 2012-2016

\begin{tabular}{llllll}
\hline Tourism Object & \multicolumn{5}{c}{ Total Revenue for Tourism Objects (Million) } \\
\cline { 2 - 6 } & 2012 & 2013 & 2014 & 2015 & 2016 \\
\hline Widuri Beach & 845.223 & 627.677 & 723.592 & 669.086 & 640.315 \\
Blendung Beach & 45.648 & 18.128 & 19.987 & 11.132 & 7.390 \\
Nyamplungsari Beach & 2 & Not Available & Not Available & Not Available & Not Available \\
\hline
\end{tabular}

Source: Department of Tourism, Youth and Sports District. Pemalang, 2017

METHOD

In this study using quantitative research methods. The population in this study were tourists visiting Blendung Beach and Nyamplungsari Beach. Calculation of samples using the Slovin formula is as many as 100 
respondents determined by accidental sampling technique. The analytical techniques used in this study are as follows:

\section{Percentage Descriptive Analysis}

To identify the carasteristics of tourist objects in Blendung Beach and Nyamplungsari Beach, a percentage descriptive analysis is used, which is an analysis that aims to describe the condition or condition and the object under study. In this study using indicators of gender, age, place of residence, level of education, marital status, occupation, tourist destination and friends.

\section{Multiple Linear Regression Analysis}

In this study multiple linear regression analysis is used to analyze the factors that influence tourist interest in purchasing decisions. Factors include various components proposed by Cooper et al (1995 in Hardiyanto, 2013). Based on previous research, the tourist interest function model is as follows:

$$
\begin{aligned}
& \mathrm{Y}=\mathrm{f}\left(\mathrm{X}_{1}, \mathrm{X}_{2}, \mathrm{X}_{3}, \mathrm{X}_{4}\right) \\
& Y=\beta o+\beta_{1} X_{1}+\beta_{2} X_{2}+\beta_{3} X_{3}+\beta_{4} X_{4}+e
\end{aligned}
$$

\section{Quantitative Descriptive Analysis}

According to Azam N, et al (2006 in DWP, S., Sutrasmawati, E., \& SW, I. (2012) Preference is defined as the choice of someone's likes or dislikes of a product or service consumed. To analyze tourist preferences for tourism objects Blendung
Beach and Nyamplungsari Beach use quantitative descriptive analysis using analytical tools namely tabulation Tabulation is a grouping of criteria into several indicators in this study which are then ranked and calculated for each indicator which will then find the mean value. Mean is the number of values of each indicator divided by the number of research respondents (Pauwah et al, 2013). In this study the indicators used are those proposed by Stanton (1999 in Gantini, 2012).

Table 4. Score Preferences and Range Score

\begin{tabular}{lll}
\hline Preferences & Score & Range \\
\hline Very Good & 5 & $4,6-5,0$ \\
Good & 4 & $3,6-4,5$ \\
Good Enough & 3 & $2,6-3,5$ \\
Not Good & 2 & $1,6-2,5$ \\
Poor & 1 & $1,0-1,5$ \\
\hline
\end{tabular}

Source: (Pauwah et al, 2013)

\section{RESULTS AND DISCUSSION}

\section{Characteristics of Respondents Tourism Objects of Blendung Beach and Nyamplungsari Beach}

Characteristics of respondents can be seen in table 5 and table 6 . Based on the table 5 the characteristics of respondents were dominated by respondents who were female, at $66 \%$ with the age of $12-18$ years at $74 \%$, the majority came from the Pemalang regency with a percentage of $72 \%$ with a junior high school education background of $56 \%$. While judging from the marital status, the majority of respondents were unmarried as much as $96 \%$ who were still students by $78 \%$ with the most tourist destinations namely recreation $44 \%$, the majority of which were done with friends with a percentage of $86 \%$. 
Table 5. Characteristics of Respondents at Blendung Beach

\begin{tabular}{|c|c|}
\hline Indicators & Percentage (\%) \\
\hline \multicolumn{2}{|l|}{ Gender } \\
\hline Male & $34 \%$ \\
\hline Female & $66 \%$ \\
\hline \multicolumn{2}{|l|}{ Age (Old) } \\
\hline \multicolumn{2}{|l|}{$12-18$} \\
\hline \multicolumn{2}{|l|}{$19-24$} \\
\hline \multicolumn{2}{|l|}{$25-31$} \\
\hline \multicolumn{2}{|l|}{$32-38$} \\
\hline \multicolumn{2}{|l|}{ Residence } \\
\hline Pemalang Regency & $72 \%$ \\
\hline Outside Pemalang Regency & $28 \%$ \\
\hline \multicolumn{2}{|l|}{ Education Backgriund } \\
\hline SD & $4 \%$ \\
\hline SMP & $56 \%$ \\
\hline SMA/SMK & $40 \%$ \\
\hline \multicolumn{2}{|l|}{ Marital Status } \\
\hline Single & $96 \%$ \\
\hline Married & $4 \%$ \\
\hline \multicolumn{2}{|l|}{ Occupation } \\
\hline student & $78 \%$ \\
\hline Entrepreneur & $14 \%$ \\
\hline Others & $8 \%$ \\
\hline \multicolumn{2}{|l|}{ Tourist Destination } \\
\hline Recession & $44 \%$ \\
\hline Rest / Relaxation & $8 \%$ \\
\hline \multicolumn{2}{|l|}{ Enjoy the view } \\
\hline Take a walk & $10 \%$ \\
\hline \multirow[t]{2}{*}{ Others } & $32 \%$ \\
\hline & $6 \%$ \\
\hline \multicolumn{2}{|l|}{ Friend } \\
\hline Partners / Friends & $86 \%$ \\
\hline Family & $10 \%$ \\
\hline Others & $4 \%$ \\
\hline
\end{tabular}

Source: Data Processed in 2018

Based on table 6 the characteristics of respondents were dominated by respondents who were female, at $76 \%$ with the age of $12-18$ years at $44 \%$, the majority came from Pemalang regency with a percentage of $96 \%$ with a high school / vocational education background of $54 \%$. While judging from the marital status, the majority of respondents were not married as much as $72 \%$ who were still as students by $60 \%$ with the most tourist destinations namely $72 \%$ recreation, the majority of which were done with friends with a percentage of $60 \%$.

Table 6. Characteristics of Respondents on Nyamplungsari Beach

\begin{tabular}{ll}
\hline Indicators & Percentage (\%) \\
\hline Gender & \\
Male & $24 \%$ \\
Female & $76 \%$ \\
Age (Old) & \\
$12-18$ & \\
$19-24$ & $44 \%$ \\
$25-31$ & $24 \%$ \\
$32-38$ & $12 \%$ \\
$>38$ & $16 \%$ \\
Residence & $4 \%$ \\
Pemalang Regency & \\
Outside Pemalang Regency & $96 \%$ \\
Education Background & $4 \%$ \\
SD & \\
SMP & $10 \%$ \\
SMA/SMK & $36 \%$ \\
Marital Status & $54 \%$ \\
Single & \\
Married & \\
Occupation & $72 \%$ \\
Student & $28 \%$ \\
Private Employees & \\
Entrepreneur & \\
Others & \\
Tourist Destination & $60 \%$ \\
Recession & \\
Enjoy the view & \\
Lainnya & \\
Friend & \\
Partners / Friends & \\
Family & \\
& \\
\hline
\end{tabular}

Source: Data Processed in 2018

Based on table 6 the characteristics of respondents were dominated by respondents who were female, at $76 \%$ with the age of $12-18$ years at $44 \%$, the majority came from Pemalang regency with a percentage of $96 \%$ with a high school / vocational education background of $54 \%$. While judging from the 
marital status, the majority of respondents were not married as much as $72 \%$ who were still as students by $60 \%$ with the most tourist destinations namely $72 \%$ recreation, the majority of which were done with friends with a percentage of $60 \%$.

Table 7. Results of Multiple Linear Regression Analysis

\begin{tabular}{|c|c|c|c|c|c|}
\hline \multirow[b]{3}{*}{ Model } & \multicolumn{5}{|c|}{ Unstandardized } \\
\hline & \multicolumn{2}{|c|}{ Unstandardized Coefficients } & \multirow{2}{*}{$\begin{array}{c}\text { Coefficients } \\
\text { Beta }\end{array}$} & \multirow[b]{2}{*}{$\mathrm{t}$} & \multirow[b]{2}{*}{ Sig. } \\
\hline & B & Std. Eror & & & \\
\hline (Constant) & 10.524 & 3.169 & & 3.321 & .002 \\
\hline Atraksi Wisata $\left(\mathrm{Xl}_{1}\right)$ & 134 & .121 & .092 & 1.113 & .272 \\
\hline Aksesbilitas (X2) & .005 & .082 & .006 & .061 & .952 \\
\hline Fasilitas $\left(\mathrm{X}_{3}\right)$ & .291 & .097 & 293 & 2.983 & .005 \\
\hline Pelayanan $\left(\mathrm{X}_{4}\right)$ & .635 & .119 & .624 & 5.325 & .000 \\
\hline
\end{tabular}

Source: Data Processed in 2018

\section{Factors Affecting Tourist Interest}

In this study the multiple linear regression analysis used was to analyze the factors that influence tourist interest in the tourist attractions of Blendung Beach and Nyamplungsari Beach. The results of multiple linear regression analysis can be seen in table 7 and table 8 below.

Based on table 7 the results of multiple regression analysis of respondents' answers regarding indicators that influence tourist interest in the Blendung Beach tourism object, it can be concluded as:

$$
\begin{aligned}
\mathrm{Y}= & 10.524+0.134 \mathrm{X}_{1}+0.005 \mathrm{X}_{2}+0.291 \mathrm{X}_{3}+ \\
& 0.635 \mathrm{X}_{4}+\mathrm{e}
\end{aligned}
$$

From the regression equation can be explained as follows:

1. In the coefficient of tourist attraction, it means that if a tourist attraction variable experiences an increase, the dependent variable that is the interest of tourists will increase.

2. In the accessibility coefficient, it means that if the accessibility variable increases, the dependent variable that is the interest of tourists will increase.

3. The facility coefficient means that if the facility variable increases, the dependent variable is the interest of tourists will increase.

4. In the service coefficient means that if the service variable is increasing, the dependent variable is the interest of tourists will increase.

Based on table 7 the results of multiple regression analysis of respondents' answers regarding indicators that influence tourist interest in the Nyamplungsari Beach tourism object, it can be concluded as:

$$
\begin{aligned}
\mathrm{Y}= & 6.178+0.485 \mathrm{X}_{1}+0.234 \mathrm{X}_{2}+0.245 \mathrm{X}_{3}+0.266 \\
& \mathrm{X}_{4}+\mathrm{e}
\end{aligned}
$$

From the regression equation can be explained as follows:

1. In the coefficient of tourist attraction, it means that if a tourist attraction variable experiences an increase, the dependent 
2. variable that is the interest of tourists will increase.

3. In the accessibility coefficient, it means that if the accessibility variable increases, the dependent variable that is the interest of tourists will increase.

4. The facility coefficient means that if the facility variable increases, the dependent variable is the interest of tourists will increases.

5. In the service coefficient means that if the service variable has increased, the dependent variable is the interest of tourists will increase.

Table 8. Results of Multiple Linear Regression Analysis (Nyamplungsari Beach)

\begin{tabular}{cccccc}
\hline & \multicolumn{2}{c}{ Unstandardized Coefficients } & Unstandardized Coefficients & & \\
Model & $\mathrm{B}$ & Std. Error & Beta & $\mathrm{t}$ & Sig. \\
\hline $\begin{array}{c}\text { (Constant) } \\
\text { Atraksi }\end{array}$ & 6.178 & 3.077 & & 2.008 & .051 \\
$\begin{array}{c}\text { Wisata }\left(\mathrm{X}_{1}\right) \\
\text { Aksesbilitas }\end{array}$ & .485 & .185 & .336 & 2.625 & .012 \\
$\quad\left(\mathrm{X}_{2}\right)$ & .234 & .112 & .220 & & \\
$\begin{array}{c}\text { Fasilitas } \\
\left(\mathrm{X}_{3}\right)\end{array}$ & .245 & .116 & & & .043 \\
$\begin{array}{c}\text { Pelayanan } \\
\left(\mathrm{X}_{4}\right)\end{array}$ & .206 & .124 & .268 & 2.106 & .041 \\
\hline
\end{tabular}

Source: Data Processed in 2018

Tourist Preference for Blendung Beach Tourism Object and Nyamplungsari Beach

Tourist preferences for Blendung Beach tourism objects include several indicators. In this study the indicators used are those put forward by Stanton (1999 in Gantini, 2012), namely 1) Tourist Attraction; 2) Facilities; 3) Accessibility; 4) Service; and 5) Comfort. Tourist preferences are influenced by what is offered by attractions so that tourists will assume that these attractions are good and interesting to visit. Tourist preferences for
Blendung Beach can be seen in Figure 1 and Figure 2.

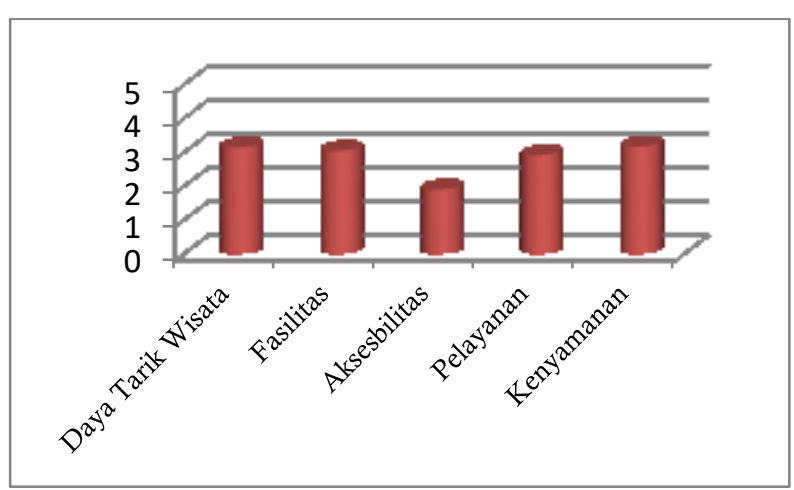

Figure 1. Tourist Preference to Blendung Beach Tourism Object

Source: Data Processed in 2018 
Based on the results of research on tourist preferences on Blendung Beach tourism objects such as Figure 1, which shows that the comfort indicator gets the highest value, which is 3,115 , which means it can be classified as a good enough category, for the tourist attraction indicator, it has a value of 3,132 which is in the good enough category. Tourism facilities get a value of 3,036, the next is a service indicator with a value of 2,913 which is categorized as good enough while accessibility has the lowest value of 1,893 which means it is in the not good category.

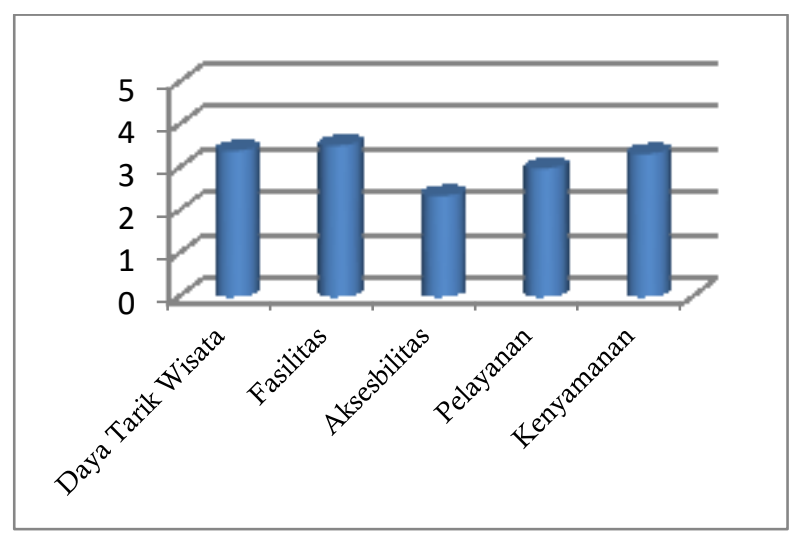

Figure 2. Tourist Preference for Nyamplungsari Beach Tourism Object.

Source: Data Processed in 2018

Based on the results of research on tourist preferences on Nyamplungsari Beach tourism objects such as Figure 2 which shows that the facility indicator gets the highest value of 3,512 which means it can be classified as a good category, for tourist attraction indicators get a value of 3,388 which is categorized good enough. Tourism comfort has a value of 3,315 , the next is the service indicator with a value of 2.89 which is categorized as good enough while accessibility has the lowest value of 2.34 which means that it is categorized good enough.
By looking at the results of tourist preference values on the tourist attractions of Blendung Beach and Nyamplungsari Beach, it can be said that the majority of tourist preferences belong to the category of good enough. To encourage increasing tourist preference, there needs to be development efforts carried out, especially on indicators that get poor and not good grades and categories so that later can attract tourists and increase the number of tourist visits to Blendung Beach and Nyamplungsari Beach.

\section{CONCLUSION}

From the results of this study it can be concluded that the factors that influence tourist interest in Blendung Beach and Nyamplungsari Beach attractions are based on the regression equation that the regression coefficients of all variables are positive and significant which means that all variables used have an influence on tourist interest.

In this study about tourist preferences on Blendung Beach tourism objects do not show the results of preferences with very good, good and bad categories on each indicator used. Indicators that have the highest preference value are convenience with a value value range of 3.155 in the category of good enough. In addition, indicators of tourist attraction, facilities and services fall into the category of good enough. While accessibility indicators are grouped into unfavorable categories with a range value of 1.893.It should illustrate brief and clear results of study, contributions to new theories, and new ideas for future researches. Here, the theoretical and practical implications should be written in paragraphs.

In Nyamplungsari Beach tourism objects tourists do not show preference values in the 
category of good, bad and not good. Indicator with the highest range value of 3.512, the facility indicator grouped in good category. Other indicators such as tourist attraction, comfort, service and accessibility show preference values in quite good categories. The accessibility indicator has the lowest range value of 2.34 .

\section{REFERENCES}

Badan Pusat Statistik Kabupaten Pemalang. (2016). Retrieved Maret Sabtu, 2017, from Pemalang Dalam Angka: http://pemalangkab.bps.go.id

Dinas Pariwisata, Pemuda dan Olahraga Kabupaten Pemalang. (2015). Retrieved Maret Monday, 2017, from http://www.pemalangkab.go.id.

DWP, S., Sutrasmawati, E., \& SW, I. (2012). Analisis Persepsi Dan Preferensi Ibu Rumah Tangga Terhadap Produk Pangan Olahan Berbasis
Tepung Ubi Jalar Dalam Meningkatkan Keanekaragaman Pangan. Jejak: Jurnal Ekonomi dan

Kebijakan,2(1).doi:https://doi.org/10.15294/jejak.v 2i1.1454.

Gantini, Kariza D. \& Setyorini, H.P.D. (2012). Pengaruh Revitalisasi Produk Wisata Terhadap Preferensi Mengunjungi Lembah Bougenville Resort. Tourism and Hospitality Essentials (THE) Journal, Volume 2 No.2. Hal 387-406. Bandung Barat : UPI.

Hardiyanto, Dwi dkk. (2013). Preferensi Konsumen Terhadap Produk Selai Buah Nipah Menggunakan Analisis Konjoin. Jurnal Teknik Industri. Malang : UB.

Republik Indonesia. 2009. Undang-Undang No. 10 Tahun 2009 tentang Kepariwisataan. Jakarta.

Yusran Pauwah Veronica A. Kumurur Rieneke L.E. Sela Oktavianus H.A. Rogi. (2013, Mei). Persepsi dan Preferensi Pengunjung Terhadap Kawasaan Wisata Pantai Malalayang. Jurnal Perencanaan Wilayah dan Kota, Vol. 5, 16-27. 